\title{
Effects of Cocaine Self-administration on Striatal Dopamine Systems in Rhesus Monkeys: Initial and Chronic Exposure
}

\author{
Michael A. Nader, Ph.D., James B. Daunais, Ph.D., Tonya Moore, M.S., Susan H. Nader, B.A., \\ Rodney J. Moore, Ph.D., Hilary R. Smith, B.A., David P. Friedman, Ph.D., and Linda J. Porrino, Ph.D.
}

The purpose of this study was to examine the time course of changes in dopamine $D_{1}$ - and $D_{2}$-like receptor densities in monkeys self-administering cocaine. Experimentally nä̈ve adult male rhesus monkeys $(n=22)$ were divided into a food reinforcement group $(n=6)$, in which responding was maintained by food presentation, or into four cocaine selfadministration groups ( $n=4 /$ group), based on dose ( 0.03 or $0.3 \mathrm{mg} / \mathrm{kg}$ per injection) and duration of exposure (5 or $\sim 100$ sessions). After the last session, monkeys were euthanized, brains were removed, frozen, and coronal sections through the striatum, rostral to the anterior commissure, were processed for $D_{1}\left(\left[{ }^{3} \mathrm{H}\right] \mathrm{SCH} 23390\right)$ and $\mathrm{D}_{2}\left(\left[{ }^{3} \mathrm{H}\right]\right.$ raclopride) receptor autoradiography. Compared with controls, there was no effect of 5 days of cocaine selfadministration on $D_{1}$ and $D_{2}$ receptors. In monkeys with extensive cocaine histories, $D_{1}$ receptor densities were significantly increased relative to controls in some parts of the striatum, while $D_{2}$ receptor densities were significantly decreased throughout the striatum. These findings demonstrate that chronic cocaine self-administration produces neuroadaptations in dopamine systems, but that these changes do not occur in a parallel fashion.

[Neuropsychopharmacology 27:35-46, 2002] (C) 2002 American College of Neuropsychopharmacology. Published by Elsevier Science Inc.
KEY WORDS: Dopamine; $D_{1}$ receptors; $D_{2}$ receptors; Cocaine abuse; Striatum; Nucleus accumbens; Rhesus monkey

Cocaine binds to monoamine transporters, resulting in elevated levels of dopamine (DA), serotonin and norepinephrine. Much research has focused on cocaine's actions within the dopaminergic system, because this neurotransmitter has been intimately linked to the high abuse liability of cocaine (e.g., Ritz et al. 1987; Roberts et

From the Department of Physiology and Pharmacology, Wake Forest University School of Medicine, Winston-Salem, NC 27157.

Address correspondence to: Michael A. Nader, Ph.D. Department of Physiology and Pharmacology, Wake Forest University School of Medicine, Medical Center Boulevard, Winston-Salem, NC 27157-1083

Phone: (336) 713-7172, Fax: (336) 713-7168, Email: mnader@wfubmc.edu

Received January 23, 2001; revised October 16, 2001; accepted November 29, 2001.

Online publication: 12/04/01 at www.acnp.org/citations/ Npp120401217. al. 1999; Woolverton and Johnson 1992). Within the DA system, there are two pharmacologically distinct families of receptors, $D_{1}$ and $D_{2}$, both of which are present in the nucleus accumbens, caudate, putamen, amygdala, and prefrontal cortex. These areas are major targets of dopaminergic neurons in the ventral midbrain and are thought to play a role in mediating the reinforcing effects of cocaine.

There is considerable evidence from rodents and primates linking $D_{1}$ and $D_{2}$ receptors to many of the behavioral effects of cocaine. For example, $\mathrm{D}_{1}$ agonists are self-administered (Self et al. 1996; Self and Stein 1992; Weed et al. 1993, 1997; Weed and Woolverton 1995) and have cocaine-like discriminative stimulus effects (Spealman et al. 1991; Sinnott and Nader 2001). Furthermore, $\mathrm{D}_{1}$ agonists and antagonists have been shown to produce dose-dependent and orderly changes in cocaine self-administration (e.g., Bergman et al. 1990; Caine et 
al. 1995; Caine and Koob 1994; Corrigall and Coen 1991; Katz and Witkin 1992; Spealman et al. 1997; Woolverton and Virus 1989). Similarly, $\mathrm{D}_{2}$ agonists are self-administered (Caine et al. 1999, 2000; Nader and Mach 1996) and also have cocaine-like discriminative stimulus effects (Lamas et al. 1996; Spealman et al. 1991; Sinnott et al. 1999). In addition, administration of $\mathrm{D}_{2}$ receptor agonists and antagonists has been shown to produce dosedependent and orderly changes in cocaine self-administration (e.g., Bergman et al. 1990; Caine and Koob 1994; Nader et al. 1999). The behavioral effects of drugs acting at $D_{1}$ and $D_{2}$ receptors clearly indicate a role for these receptor subtypes in mediating the actions of cocaine.

Efforts to determine the neurobiological consequences of cocaine administration, especially as it pertains to the dopaminergic system, have produced mixed results. For example, "chronic" cocaine treatment in rodents has been reported to increase, decrease, or not change $\mathrm{D}_{1}$ and/or $\mathrm{D}_{2}$ receptor densities (e.g., Dwoskin et al. 1988; Goeders and Kuhar 1987; Kleven et al. 1990; Lim et al. 1990; Maggos et al. 1998; Memo et al. 1981; Peris et al. 1990; Taylor et al. 1979; Trulson and Ulissey 1987). These divergent results may be due to different dosing regimens (i.e., drug dose, freuency of drug administration per day), length of "chronic" administration, which rarely exceeded two weeks, withdrawal periods and the ligands used in autoradiography. In addition, previous studies have used non-contingent cocaine administration, rather than cocaine self-administration procedures. There is evidence, however, suggesting that the effects of cocaine (and other drugs of abuse) are different depending on whether the drug is self-administered by the animal or administered by the experimenter (e.g., Bradberry 2000; Dworkin et al. 1995; Stefanski et al. 1999). As a result, the present study utilized cocaine self-administration, in which reinforcing doses of cocaine were studied.

In humans, positron emission tomography (PET) studies have shown significantly lower $D_{2}$ receptor binding potential in cocaine abusers than in control subjects (Volkow et al. 1990, 1993). In contrast, analysis of post-mortem tissue from people who died from cocaine overdose as compared with age-matched controls, showed no differences in $\mathrm{D}_{2}$ receptor density in the striatum (Staley and Mash 1996) or in $D_{1}$ and $D_{2}$ mRNA from the nucleus accumbens, dorsal striatum, or substantia nigra (Meador-Woodruff et al. 1993). Thus, at present the relationship between chronic cocaine exposure and changes in $\mathrm{D}_{1}$ and $\mathrm{D}_{2}$ receptor densities in humans is unclear.

Three studies have examined the effects of chronic cocaine administration on $D_{1}$ and $D_{2}$ receptors in monkeys. Farfel et al. (1992) found that after 14 days of cocaine treatment followed by 14 days withdrawal, $\mathrm{D}_{1}$ receptor densities were decreased, while $D_{2}$ receptor densities were not changed compared with control values. Unfortunately, it is not clear whether the effects were due to chronic cocaine, the withdrawal period, or both. We have reported that in monkeys with an extensive history of cocaine self-administration $(>18$ months), both $\mathrm{D}_{1}$ and $\mathrm{D}_{2}$ receptor levels were downregulated compared with controls (Moore et al. 1998a,b). These studies highlight the importance of dose, duration of exposure, and contingency of drug presentation on the neuroadaptions from chronic drug use. The primary goal of the present study, therefore, was to systematically examine the effects of both dose and duration of cocaine exposure on $D_{1}$ and $D_{2}$ receptor densities in monkeys self-administering cocaine.

\section{METHODS}

\section{Behavioral Manipulations}

Subjects. Twenty-four experimentally naive adult male rhesus monkeys (Macaca mulatta), weighing $7.6-11.5 \mathrm{~kg}$ at the start of the study, served as subjects. Monkeys were individually housed in stainless steel cages with water ad libitum; animals had visual and auditory contact with each other. Their body weights were maintained at approximately $90-95 \%$ of free-feeding weights, by banana-flavored pellets earned during the experimental sessions and by supplemental feeding of Lab Diet Monkey Chow, no sooner than 30 min post session. Each monkey was weighed once a week and, if necessary, their diets were adjusted to maintain weights. In addition, they were given fresh fruit or peanuts two to three times per week. Monkeys lived in temperature- and humidity-controlled colony rooms with lighting on from 6 A.M. to 8 P.M. All procedures were performed in accordance with established practices as described in the National Institutes of Health Guide for Care and Use of Laboratory Animals. In addition, all procedures were reviewed and approved by the Animal Care and Use Committee of Wake Forest University.

\section{Surgery}

Intravenous Catheters. Each monkey was surgically prepared, under sterile conditions, with an indwelling intravenous catheter and vascular access port (Model GPV, Access Technologies, Skokie, IL). Monkeys were anesthetized with a combination of ketamine $(15 \mathrm{mg} /$ $\mathrm{kg}$, i.m.) and butorphanol ( $0.03 \mathrm{mg} / \mathrm{kg}$, i.m. $)$ and an incision was made near the femoral vein. After blunt dissection and isolation of the vein, the proximal end of the catheter was inserted into the vein for a distance calculated to terminate in the vena cava. The distal end of the catheter was threaded subcutaneously to an incision made slightly off the midline of the back. The vascular 
access port was placed within a pocket formed by blunt dissection near the incision. Prior to each experimental session, the back of the animal was cleaned with $95 \%$ ETOH and betadine scrub and a 22 gauge Huber Point Needle (Model PG20-125) was inserted into the port leading to the venous catheter, connecting an infusion pump, containing the cocaine solution, to the catheter. The pump was operated for approximately $3 \mathrm{~s}$, filling the port with the dose of cocaine that was available during the experimental session. At the end of each session, the port was filled with heparinized saline (100 Units/ml) to help prevent clotting.

Intraarterial Catheters. Approximately five days before the terminal procedure, each monkey was implanted with a chronic indwelling catheter into the femoral artery. The procedures were identical to those described for the venous catheters. For monkeys in the "initial" cocaine self-administration groups (see below), this catheter was implanted at the same time as the venous catheter. On the final session, a terminal glucose metabolism study was conducted (see Lyons et al. 1996 for details). In this procedure, monkeys were injected with $2-\left[{ }^{14} \mathrm{C}\right]$ deoxyglucose (2-DG) approximately $2 \mathrm{~min}$ after the end of the session and blood samples were obtained through the arterial catheter over a $45 \mathrm{~min}$ period. No metabolism data will be presented.

\section{Apparatus}

Cocaine self-administration and food-reinforced responding occurred in ventilated and sound-attenuated chambers $(150 \times 74 \times 76 \mathrm{~cm}$, Med Associated, East Fairfield, VT) designed to accommodate a primate chair (Model R001, Primate Products, Redwood City, CA). An intelligence panel $(48 \times 69 \mathrm{~cm})$, located on the right side of the chamber, contained two retractable levers $(5 \mathrm{~cm}$ wide) with three small stimulus lights centrally located $14 \mathrm{~cm}$ above each lever. The levers were positioned to be within easy reach of the monkey sitting in the primate chair. One gram food pellets were delivered into a food receptacle located on the intelligence panel, between the two levers. A peristaltic infusion pump (7531-10, Cole-Parmer Co., Chicago, IL) for delivering drug injections at a rate of approximately $1 \mathrm{ml} / 10 \mathrm{~s}$, was located on the top of the chamber. Operation of the chambers and data acquisition were accomplished with a computer system (Power Macintosh and Med Associates interface).

\section{Procedures}

Each monkey was fitted with an aluminum collar (Model B008, Primate Products) and trained to approach the front of the cage when the investigator was present. A stainless steel rod (Model R011, Primate Products) with a latch on the end was attached to the collar and the monkey was guided into the primate restraint chair. The monkey, seated in the primate chair, was then wheeled into the experimental chamber. Monkeys were initially trained to respond on the left lever by reinforcing each response with a $1 \mathrm{~g}$ banana-flavored pellet. Over approximately three weeks, the interval between food pellet availability was gradually increased until a 3-min interval was obtained (i.e., a fixed-interval 3-min schedule; FI 3-min). Under the final schedule conditions, the first response on the lever after $3 \mathrm{~min}$ resulted in food pellet delivery; sessions ended after 30 food presentations. All monkeys continued to respond under the FI 3-min schedule of food presentation for at least 20 sessions and until stable performance was obtained ( $\pm 20 \%$ of the mean for three consecutive sessions, with no trends in response rates). When food-maintained responding was stable, the feeder was unplugged and the effects of extinction on responding were examined for five consecutive sessions. After this extinction period, responding was re-established and maintained by food presentation. Because saline was not studied after cocaine self-administration had been established (see below), rates of responding during extinction of food-maintained responding were used to confirm that cocaine was functioning as a reinforcer.

\section{Experimental Groups}

After two to three months and when baseline food-reinforced performance had been established, all monkeys were surgically prepared with a venous catheter, as described above, and randomly assigned to one of six groups. Two groups of monkeys (initially $n=4$ /group) served as controls and continued to respond under the FI 3-min schedule of food presentation. The remaining 16 monkeys were assigned to one of four cocaine self-administration groups ( $\mathrm{n}=4$ /group): (1) initial (5-day) exposure, low-dose cocaine self-administration group $(0.03$ $\mathrm{mg} / \mathrm{kg}$ per injection); (2) initial exposure, high-dose cocaine self-administration group ( $0.3 \mathrm{mg} / \mathrm{kg}$ per injection); (3) chronic ( 100 days) exposure, low dose group; and (4) chronic exposure, high dose group. Over the course of the chronic study, two monkeys (one from each self-administration group) became ill and had to be removed from the study. They were replaced by two monkeys that were initially designated as control subjects. As a result, the chronic control group is $n=2$. Food-maintained performance was allowed to stabilize after surgery (approximately 4-6 days) before cocaine self-administration sessions were begun. Because $0.3 \mathrm{mg} / \mathrm{kg}$ cocaine per injection was considered a high dose for previously cocaine-naïve monkeys, for most animals this dose was achieved within two sessions by first allowing the monkey to self-administer $0.1 \mathrm{mg} / \mathrm{kg}$ cocaine per injection. For all groups, responding was maintained under an FI 3- 
min schedule and sessions ended after 30 reinforcer presentations. Experimental sessions were conducted seven days per week, at approximately the same time each day. Mean total cocaine intakes ( \pm S.E.M.) for each group are shown in Table 1. At the end of the exposure period, monkeys were humanely euthanized with an overdose of pentobarbital (100 mg/kg, i.v.).

\section{Probe Sessions}

In an effort to develop a model of "craving," monkeys in the chronic self-administration groups and their food-maintained control monkeys, were exposed to "probe" sessions approximately every 14 days. A probe session consisted of a period of abstinence $(1,2$ or 3 days) followed by a 2-h experimental session in which the schedule of reinforcement was FI $2 \mathrm{~h}$. During abstinence periods, the monkey was placed in the restraint chair, his catheter was flushed with heparinized saline (100 Units/ml) and he was returned to his homecage. Each abstinence period/probe session was evaluated twice throughout the course of the experiment, with the order of testing occurring in a semi-random fashion. The final probe session occurred at least two weeks before the terminal 2-DG procedure. Data from these probe studies are not presented here.

\section{Data Analysis}

The primary dependent variables for the self-administration studies were response rates and cocaine intake. Data are presented as the mean ( \pm 1 S.E.M.) for all monkeys in a group. Data were analyzed using repeated measures analysis of variance (ANOVA). For the chronic studies, data are plotted as means from blocks of 10 sessions; main effects were Group (Food, Coc 0.03 and Coc 0.3) and Blocks (from 1-10). For all analyses, $p<.05$ was considered statistically significant. In addition, quarter-life (QL), which is an index of pattern of responding under FI schedules (Catania and
Reynolds 1968) was calculated for performance from both chronic cocaine self-administration groups. QL values represent the proportion of the FI elapsed when $25 \%$ of the responses in that interval had occurred. To calculate QL values, the interval (3 min) was divided into 10 bins (18 s/bin) and responses in each bin were tabulated across the entire session. Larger QL values represent greater responding late in the FI; QL values larger than 0.25 are characteristic of "schedule-appropriate" responding.

\section{Tissue Processing}

After euthanasia, brains were immediately removed, blocked, and frozen in isopentane at $-35^{\circ}$ to $-55^{\circ} \mathrm{C}$ and then stored at $-80^{\circ} \mathrm{C}$. The tissue blocks containing the striatum were then cut in a cryostat at $-20^{\circ} \mathrm{C}$ in the coronal plane into $20-\mu \mathrm{m}$ sections, collected onto subbed or electrostatically charged slides, desiccated under a vacuum overnight at $4^{\circ} \mathrm{C}$, then stored at $-80^{\circ} \mathrm{C}$ until used.

Brain sections for autoradiographic processing were collected from the portions of the caudate, putamen, and nucleus accumbens that lie rostral to the anterior commissure. We refer to this region as the precommissural striatum (PCS). Further, rostral and caudal levels of the PCS were designated with reference to the nucleus accumbens. The rostral PCS is the region where the accumbens is not differentiated into distinct shell and core subcompartments. The caudal PCS is the region congruent with the appearance of the shell and core of the nucleus accumbens, which is posterior to the emergence of the olfactory tubercle. For each of the binding studies, two adjacent sections were taken at five levels through the PCS, for a total of ten sections per animal. Separate binding assays were conducted for tissue from animals exposed for 5 days and 100 days of cocaine presentation. Tissue from one food-reinforced control animal that had responded for 5 days was processed along with tissue from animals treated for 100 days.

Table 1. Performance of Monkeys Responding under a Fixed-interval 3-min Schedule ${ }^{t}$

\begin{tabular}{lcccc}
\hline Group & $\begin{array}{c}\text { Food-maintained } \\
\text { Response Rate } \\
(\mathbf{r} / \mathbf{s})\end{array}$ & $\begin{array}{c}\text { Extinction } \\
\mathbf{( \% ~ b a s e l i n e )}\end{array}$ & $\begin{array}{c}\text { Cocaine-maintained } \\
\text { Response Rate } \\
(\mathbf{r} / \mathbf{s})\end{array}$ & $\begin{array}{c}\text { Total Cocaine } \\
\text { Intake (mg/kg) }\end{array}$ \\
\hline Initial Food & $0.13(.03)$ & $32.06(23.3)$ & - & - \\
Initial-0.03 & $0.11(.03)$ & $1.93(.72)$ & $0.05(.02)$ & $4.50(0.0)$ \\
Initial-0.3 & $0.13(.04)$ & $12.58(4.9)$ & $0.01(.00)$ & $45.98(.75)$ \\
Chronic-Food & $0.17(.16)$ & $5.51(7.55)$ & - & - \\
Chronic-0.03 & $0.40(.09)$ & $33.10(16.7)$ & $0.10(.05)$ & $103.22(3.3)$ \\
Chronic-0.3 & $0.28(.11)$ & $30.32(27.8)$ & $0.03(.02)$ & $990.00(60.7)$ \\
\hline
\end{tabular}

\footnotetext{
${ }^{\dagger}$ Each point represents 3-day mean data from four monkeys (except Food Controls; Initial $\mathrm{n}=4$; Chronic $\mathrm{n}=2$ ).

$\S$ Mean rate from last 3 sessions prior to terminal procedure.
} 


\section{$D_{1}$ Binding}

Dopamine $\mathrm{D}_{1}$ receptor binding site densities were determined with [ $\left.{ }^{3} \mathrm{H}\right] \mathrm{SCH} 23390$ (New England Nuclear, Boston, MA) by quantitative in vitro receptor autoradiography according to procedures adapted from Lidow et al. (1991) and Bardo and Hammer (1991). For binding studies in the striatum, sections were preincubated for $20 \mathrm{~min}$ in buffer $\left(50 \mathrm{mM}\right.$ Tris buffer, $\mathrm{pH} 7.4,25^{\circ} \mathrm{C}$, containing $120 \mathrm{mM} \mathrm{NaCl}, 5 \mathrm{mM} \mathrm{KCl}, 2 \mathrm{mM} \mathrm{CaCl} 2,1 \mathrm{mM}$ $\mathrm{MgCl}_{2}$ ) to remove endogenous DA and ${ }^{14} \mathrm{C}$ from the deoxyglucose procedure. Sections were then incubated for $30 \mathrm{~min}$ in the same buffer, $\mathrm{pH} 7.4,25^{\circ} \mathrm{C}$, containing $1 \mathrm{mM}$ ascorbic acid, $40 \mathrm{nM}$ ketanserin, and $1 \mathrm{nM}$ $\left[{ }^{3} \mathrm{H}\right] \mathrm{SCH}$ 23390. After incubation, sections were rinsed for $20 \mathrm{~s} \times 2$ in buffer containing $1 \mathrm{mM}$ ascorbic acid at pH 7.4, $4^{\circ} \mathrm{C}$, then dipped in distilled $\mathrm{H}_{2} \mathrm{O}$ at $4^{\circ} \mathrm{C}$, and dried under a stream of cool air. Non-specific binding was defined by incubation of adjacent sections in the incubation solution in the presence of $5 \mu \mathrm{M}(+)$-butaclamol. Sections, along with calibrated $\left[{ }^{3} \mathrm{H}\right]$ autoradiographic standards (Amersham, Arlington Heights, IL), were apposed to Hyperfilm (Amersham) for three weeks.

\section{$\mathrm{D}_{2}$ Binding}

The density and distribution of dopamine $\mathrm{D}_{2}$ receptor binding sites were determined with $\left[{ }^{3} \mathrm{H}\right]$ raclopride (New England Nuclear) according to procedures adapted from Lidow et al. (1991). Sections were preincubated $20 \mathrm{~min}$ in buffer ( $50 \mathrm{mM}$ Tris buffer, $\mathrm{pH} 7.4,25^{\circ} \mathrm{C}$, containing $120 \mathrm{mM} \mathrm{NaCl}, 5 \mathrm{mM} \mathrm{KCl}$ ) to remove endogenous DA and ${ }^{14} \mathrm{C}$ from the deoxyglucose procedure. Sections were then incubated for $30 \mathrm{~min}$ in the same buffer, $\mathrm{pH}$ $7.4,25^{\circ} \mathrm{C}$, containing $0.1 \%$ ascorbic acid and $2 \mathrm{nM}$ $\left[{ }^{3} \mathrm{H}\right]$ raclopride. After incubation, sections were rinsed six times for $60 \mathrm{~s}$ in buffer at $\mathrm{pH} 7.4,4^{\circ} \mathrm{C}$, then dipped in distilled $\mathrm{H}_{2} \mathrm{O}$ at $4^{\circ} \mathrm{C}$, and dried under a stream of cool air. Non-specific binding was defined by incubation of adjacent sections in the incubation solution in the presence of $1 \mu \mathrm{M}(+)$-butaclamol. Sections, along with calibrated $\left[{ }^{3} \mathrm{H}\right]$ autoradiographic standards, were apposed to Hyperfilm for five weeks.

\section{Densitometry and Data Analysis}

Films were processed with Kodak GBX developer, stopbath, Rapid Fixer, and rinsed. Analysis of autoradiography was conducted by quantitative densitometry with a computerized image processing system (MCID, Imaging Research, St. Catharines, Ontario). Optical density values were converted to $\mathrm{fmol} / \mathrm{mg}$ (of wet-weight tissue) by reference to the Amersham ${ }^{3} \mathrm{H}$ microscale standards. Specific binding was determined by digitally subtracting images of nonspecific binding from superimposed adjacent images of total binding. Structures were iden- tified by Nissl staining of sections adjacent to those analyzed for receptor binding. Because assays of tissue from the initial and chronic groups were conducted separately, data from each individual assay was analyzed independently by means of a one-way analysis of variance followed by Dunnett's tests for multiple comparisons. Each region comprised a separate analysis. In order to facilitate comparisons across assays, the data presented in Tables 2 and 3 were normalized to one another. Normalization was based on a factor derived from the mean values obtained from adjacent sections of some control animals processed in each of the two assays. Normalization did not change the statistical results in any way.

\section{RESULTS}

\section{Cocaine Self-administration}

All monkeys were initially trained to respond under an FI 3-min schedule of food presentation, prior to being divided into one of six groups. After approximately 20-30 sessions of food-reinforced responding, mean response rates were not different between any of the groups (Table 1; second column). When the food pellet dispenser was unplugged and extinguished responding was studied for five consecutive sessions, response rates were significantly $(p<.01)$ decreased in all monkeys (Table 1; third column). After food-maintained responding was re-established, catheters were placed in the monkeys and cocaine self-administration was initiated.

Initial Cocaine Self-administration For control monkeys, mean rates of food-maintained responding declined with experience under the FI schedule, from a baseline rate of $0.13 \mathrm{r} / \mathrm{s}$ to a mean rate of $0.05 \mathrm{r} / \mathrm{s}$ at the end of the study. Similar declines have been observed in monkeys responding under FI schedules (e.g., Nader and Reboussin 1994). Separate groups of monkeys ( $\mathrm{n}=$ 4 /group) were allowed to self-administer either 0.03 or $0.3 \mathrm{mg} / \mathrm{kg}$ cocaine per injection during daily sessions. This was accomplished by simply substituting cocaine injections for food presentations. After five days of cocaine exposure, mean rate of responding maintained by $0.03 \mathrm{mg} / \mathrm{kg}$ cocaine per injection was $0.05 \mathrm{r} / \mathrm{sec}$ compared with a mean rate of $0.01 \mathrm{r} / \mathrm{sec}$ maintained by 0.3 $\mathrm{mg} / \mathrm{kg}$ cocaine per injection (Table 1 ); these rates were significantly different from each other $(p<.05)$. Compared with food extinction, responding maintained by $0.03 \mathrm{mg} / \mathrm{kg}$ cocaine per injection engendered more responses, shorter session lengths and, consequently, higher response rates $(0.05$ vs. $0.002 \mathrm{r} / \mathrm{sec})$ indicating that cocaine was functioning as a reinforcer during these five sessions of availability. Over the five consecutive sessions that cocaine was available, each monkey received the maximum number of injections per session 
Table 2. Effects of cocaine self-administration on receptor densities of $\left[{ }^{3} \mathrm{H}\right] \mathrm{SCH} 23390$ binding to $\mathrm{D}_{1}$ receptors assessed at rostral and caudal levels of the pre-commissural striatum of rhesus monkeys. Mean (S.E.M.) data sampled at two levels of the striatum (rostral and caudal) are presented as specific binding in fmols $/ \mathrm{mg}$ of wet-weight tissue and \% change from controls ${ }^{\dagger}$.

\begin{tabular}{|c|c|c|c|c|c|c|}
\hline \multirow[b]{2}{*}{ Sampled Areas } & \multicolumn{3}{|c|}{ Initial $^{\S}$} & \multicolumn{3}{|c|}{ Chronic } \\
\hline & Food-group & Coc 0.03 & Coc 0.3 & Food-group & Coc 0.03 & Coc 0.3 \\
\hline \multicolumn{7}{|l|}{ Rostral } \\
\hline \multicolumn{7}{|l|}{ Caudate } \\
\hline dorsolateral & $80.8(4)$ & $82.6(4)[2.3 \%]$ & $82.6(5)[2.3 \%]$ & $78.0(2)$ & $77.5(4)[-0.6 \%]$ & 92.1 (8) [18.1\%] \\
\hline dorsomedial & $98.4(5)$ & $102.1(6)[3.8 \%]$ & $98.1(3)[-0.4 \%]$ & $102.5(6)$ & $104.7(3)[2.9 \%]$ & $110.0(10)[7.3 \%]$ \\
\hline central & $90.7(4)$ & $90.2(5)[-0.6 \%]$ & $90.1(4)[-0.7 \%]$ & $84.9(1)$ & $90.2(3)[6.2 \%]$ & $97.5(8)[14.8 \%]$ \\
\hline ventromedial & $90.4(3)$ & $87.6(7)[-3.2 \%]$ & $90.1(2)[-0.4 \%]$ & $77.0(3)$ & 88.0 (2) [14.3\%] & $91.4(4)[18.7 \%]$ \\
\hline \multicolumn{7}{|l|}{ Putamen } \\
\hline dorsal & $90.6(5)$ & $88.5(4)[-2.4 \%]$ & $88.7(3)[-2.1 \%]$ & $88.1(2)$ & $87.2(3)[-1.0 \%]$ & $100.9(11)[14.5 \%]$ \\
\hline central & $87.6(3)$ & $92.4(5)[5.4 \%]$ & $92.4(3)[5.4 \%]$ & $89.4(2)$ & $89.9(3)[0.6 \%]$ & $94.5(9)[5.7 \%]$ \\
\hline ventral & $84.6(4)$ & $88.9(6)[5.1 \%]$ & $91.4(3)[8.1 \%]$ & $84.1(3)$ & 92.5 (5) [10.0\%] & $92.6(6)[10.1 \%]$ \\
\hline \multicolumn{7}{|l|}{ Nucleus } \\
\hline accumbens & $71.5(2)$ & $78.6(9)[10.0 \%]$ & 81.9 (3) [14.7\%] & $76.6(4)$ & 86.0 (3) [12.2\%] & $83.9(5)$ [9.5\%] \\
\hline \multicolumn{7}{|l|}{ Caudal } \\
\hline \multicolumn{7}{|l|}{ Caudate } \\
\hline dorsolateral & $88.6(7)$ & $93.0(5)[5.0 \%]$ & $90.2(8)[1.8 \%]$ & $74.2(1)$ & $80.0(1)[7.8 \%]^{*}$ & $81.5(2)[9.8 \%]^{*}$ \\
\hline dorsomedial & $96.7(8)$ & $99.4(7)[2.7 \%]$ & $97.0(6)[0.3 \%]$ & $98.2(4)$ & $106.5(3)[8.4 \%]$ & $106.1(4)[8.0 \%]$ \\
\hline central & $78.7(5)$ & $84.5(6)[7.3 \%]$ & $80.2(6)[1.8 \%]$ & $88.0(2)$ & $92.2(2)[4.7 \%]$ & $92.4(4)[5.0 \%]$ \\
\hline ventromedial & $73.8(7)$ & $79.2(5)[7.4 \%]$ & $73.2(4)[-0.8 \%]$ & $58.1(2)$ & $72.5(3)[24.8 \%]^{*}$ & $74.3(2)[27.9 \%]^{*}$ \\
\hline \multicolumn{7}{|l|}{ Putamen } \\
\hline dorsal & $77.1(6)$ & 86.9 (4) [12.7\%] & $80.1(8)[3.9 \%]$ & $77.2(2)$ & $80.1(1)[3.8 \%]$ & 88.5 (3) $[14.6 \%]^{*}$ \\
\hline central & $76.6(5)$ & 86.7 (5) $[13.2 \%]$ & $81.0(8)[5.7 \%]$ & $79.7(3)$ & $82.2(1)[3.1 \%]$ & $87.3(3)[9.5 \%]^{*}$ \\
\hline ventral & $74.0(6)$ & $82.1(4)[11.0 \%]$ & $76.4(6)[3.3 \%]$ & $84.0(1)$ & 85.1 (1) [1.3\%] & $86.4(3)[2.9 \%]$ \\
\hline \multicolumn{7}{|l|}{$\begin{array}{l}\text { Nucleus } \\
\text { accumb }\end{array}$} \\
\hline $\begin{array}{l}\text { accumben } \\
\text { core }\end{array}$ & $57.1(6)$ & 64.1 (4) $[12.2 \%]$ & $60.1(2)[5.1 \%]$ & $62.2(6)$ & $65.0(5)[4.5 \%]$ & $60.3(0)[-3.1 \%]$ \\
\hline shell & $67.6(6)$ & $66.8(4)[-1.1 \%]$ & $62.2(3)[-7.9 \%]$ & $67.4(4)$ & $77.1(3)[14.4 \%]^{*}$ & $73.1(2)[8.4 \%]^{*}$ \\
\hline \multicolumn{7}{|l|}{ Olfactory } \\
\hline tubercle & $121.7(11)$ & $111.5(13)[-8.4 \%]$ & $123.4(7)[1.4 \%]$ & 116.7 (19) & $158.5(8)[35.8 \%]^{*}$ & $146.6(9)[25.6 \%]^{*}$ \\
\hline
\end{tabular}

${ }^{+}$Data points are averages of $2-3$ sections in control groups $(\mathrm{n}=3$ monkeys) and cocaine groups $(\mathrm{n}=4$ monkeys).

$\S$ Data are normalized to chronic monkey data for comparison purposes only. Statistics were performed on untransformed data for each time point.

${ }^{*} \mathrm{p}<.05$, Dunnett's post-hoc test.

(i.e., 30), which totaled, over the course of the study, 4.5 and $45 \mathrm{mg} / \mathrm{kg}$ cocaine for the low- and high-dose groups, respectively (see Table 1 ).

Chronic Cocaine Self-administration. For monkeys in the "chronic" group, the reinforcer (food, 0.03 or 0.3 $\mathrm{mg} / \mathrm{kg}$ cocaine per injection) remained constant for approximately 100 consecutive sessions. For all monkeys, response rates declined with continued exposure to the FI schedule (Figure $1 ; p<.05$ ). These decreases in response rates were paralleled by increases in quarter-life values (a measure of pattern of responding), suggesting that continued exposure to FI contingencies results in declines in response rates due to more efficient performance, and not due to tolerance to the reinforcing effects of the stimulus. At the end of the study, QL values were $0.47( \pm 0.03)$ and $0.57( \pm 0.11)$ for the low- and high-dose groups, respectively, indicating scheduleappropriate responding. For monkeys self-administering cocaine, response rates maintained by $0.03 \mathrm{mg} / \mathrm{kg}$ cocaine per injection were significantly higher $(p<.05)$ than rates maintained by $0.3 \mathrm{mg} / \mathrm{kg}$ cocaine per injection (Figure 1 and Table 1).

\section{Effects of Cocaine Self-administration on $\mathrm{D}_{1}$ Receptor Binding in the Striatum}

Concentrations of $\left[{ }^{3} \mathrm{H}\right] \mathrm{SCH} 23390$ binding to dopamine $\mathrm{D}_{1}$ receptors in the precommissural striatum (PCS), expressed in $\mathrm{fmol} / \mathrm{mg}$ wet-weight tissue, are shown in Table 2. For the purpose of analysis, there were two separate control groups ( $n=3$ /group). There were no statistically significant differences in any measure of $\mathrm{D}_{1}$ receptor binding between control groups. Specific binding with $\left[{ }^{3} \mathrm{H}\right] \mathrm{SCH}$ 23390 accounted for greater than $90 \%$ of total binding. The distribution of binding to $\mathrm{D}_{1}$ receptors within the striatum was assessed at two levels that included the rostral PCS where the nucleus accumbens is not readily differentiable into distinct core and shell compartments and the caudal PCS where the shell of the nucleus accumbens can be clearly distinguished from the core. The caudate at both 
Table 3. Effects of cocaine administration on receptor densities of $\left[{ }^{3} \mathrm{H}\right]$ raclopride binding to $\mathrm{D}_{2}$ receptors assessed at rostral and caudal levels of precommissural striatum of rhesus monkeys. Mean (S.E.M.) data sampled at two levels of the striatum (rostral and caudal) are presented as specific bindings in fmols $/ \mathrm{mg}$ of wet-weight tissue and $\%$ change from controls ${ }^{\dagger}$.

\begin{tabular}{|c|c|c|c|c|c|c|}
\hline \multirow[b]{2}{*}{ Sampled Areas } & \multicolumn{3}{|c|}{ Initial $^{\S}$} & \multicolumn{3}{|c|}{ Chronic } \\
\hline & Food-group & Coc 0.03 & Coc 0.3 & Food-group & Coc 0.03 & Coc 0.3 \\
\hline \multicolumn{7}{|l|}{ Rostral } \\
\hline \multicolumn{7}{|l|}{ Caudate } \\
\hline dorsolateral & $92.9(7)$ & $81.7(6)[-12.1 \%]$ & $86.2(6)[-7.3 \%]$ & $94.4(2)$ & $81.9(2)[-13.2 \%]^{*}$ & $85.4(5)[-9.5 \%]^{*}$ \\
\hline dorsomedial & $93.2(8)$ & $83.4(5)[-10.6 \%]$ & $83.5(5)[-10.4 \%]$ & $94.2(3)$ & $83.1(3)[-11.8 \%]$ & $83.1(4)[-11.8 \%]$ \\
\hline central & $92.7(7)$ & $80.2(5)[-13.5 \%]$ & $85.0(7)[-8.3 \%]$ & $96.7(2)$ & $84.8(3)[-12.3 \%]^{*}$ & $85.5(3)[-11.6 \%]^{*}$ \\
\hline ventromedial & $84.9(7)$ & $78.4(5)[-7.6 \%]$ & $79.5(4)[-6.3 \%]$ & $87.3(7)$ & $88.6(4)[1.5 \%]$ & $78.0(3)[-10.6 \%]^{*}$ \\
\hline \multicolumn{7}{|l|}{ Putamen } \\
\hline dorsal & $105.5(7)$ & $91.3(5)[-13.5 \%]$ & $95.0(8)[-10.0 \%]$ & $103.8(2)$ & $94.1(1)[-9.3 \%]^{*}$ & $91.9(4)[-11.5 \%]^{*}$ \\
\hline central & $97.4(6)$ & $86.3(5)[-11.4 \%]$ & $87.1(5)[-10.6 \%]$ & $96.6(4)$ & $89.9(3)[-6.9 \%]$ & $86.0(2)[-11.0 \%]^{*}$ \\
\hline ventral & $90.1(5)$ & $79.2(5)[-12.1 \%]$ & $79.0(4)[-12.3 \%]$ & $85.6(1)$ & $82.4(2)[-3.7 \%]$ & $80.9(3)[-5.5 \%]$ \\
\hline Nucleus accumbens & $81.2(6)$ & $74.1(4)[-8.7 \%]$ & $71.0(3)[-12.5 \%]$ & $78.0(5)$ & $74.1(3)[-5.0 \%]$ & $73.6(4)[-5.6 \%]$ \\
\hline \multicolumn{7}{|l|}{ Caudal } \\
\hline \multicolumn{7}{|l|}{ Caudate } \\
\hline dorsolateral & $95.3(3)$ & $94.9(4)[-0.4 \%]$ & $92.0(6)[-3.5 \%]$ & $94.2(6)$ & $79.1(2)[-16.0 \%]^{*}$ & $79.3(3)[-15.8 \%]^{*}$ \\
\hline dorsomedial & $91.2(2)$ & $94.1(5)[3.1 \%]$ & $88.3(6)[-3.2 \%]$ & $87.3(1)$ & $80.3(3)[-8.0 \%]$ & $74.9(4)[-14.2 \%]^{*}$ \\
\hline central & $89.9(4)$ & $91.5(5)[1.8 \%]$ & $88.9(5)[-1.1 \%]$ & $94.2(5)$ & $84.7(2)[-10.0 \%]$ & $81.1(5)[-13.9 \%]^{*}$ \\
\hline ventromedial & $66.1(5)$ & $70.4(4)[6.6 \%]$ & $64.5(3)[-2.4 \%]$ & $79.6(4)$ & $71.6(5)[-10.1 \%]$ & $62.4(2)[-21.6 \%]^{*}$ \\
\hline \multicolumn{7}{|l|}{ Putamen } \\
\hline dorsal & $99.7(6)$ & $97.3(5)[-2.4 \%]$ & $97.8(7)[-1.9 \%]$ & $96.0(4)$ & $87.0(3)[-9.4 \%]$ & $83.5(3)[-13.0 \%]^{*}$ \\
\hline central & $92.7(5)$ & $91.4(3)[-1.3 \%]$ & $87.7(7)[-5.4 \%]$ & $88.7(4)$ & $83.7(3)[-5.6 \%]$ & $76.9(2)[-13.3 \%]^{*}$ \\
\hline ventral & $80.2(3)$ & $81.9(2)[2.1 \%]$ & $76.1(4)[-5.1 \%]$ & $78.0(5)$ & $74.6(3)[-4.4 \%]$ & $69.1(2)[-11.4 \%]^{*}$ \\
\hline \multicolumn{7}{|l|}{ Nucleus accumbens } \\
\hline core & $61.0(2)$ & $64.5(4)[5.7 \%]$ & $58.2(1)[-4.5 \%]$ & $63.1(2)$ & $55.6(2)[-11.9 \%]^{*}$ & $50.2(2)[-20.4 \%]^{*}$ \\
\hline shell & $67.0(2)$ & $73.8(4)[10.1 \%]$ & $64.9(2)[-3.2 \%]$ & $69.5(3)$ & $59.4(2)[-14.5 \%]^{*}$ & $50.7(4)[-27.1 \%]^{*}$ \\
\hline
\end{tabular}

${ }^{+}$Data points are averages of 2-3 sections in control groups ( $n=3$ monkeys) and cocaine groups $(n=4$ monkeys).

$\S$ Data are normalized to chronic monkey data for comparison purposes only. Statistics were performed on untransformed data for each time point. ${ }^{*} \mathrm{p}<.05$, Dunnett's post-hoc test.

rostral and caudal levels was further subdivided into dorsomedial, dorsolateral, central, and ventral regions. The putamen at both rostral and caudal levels was also further subdivided into dorsal, central and ventral putamen.

The binding of $\left[{ }^{3} \mathrm{H}\right] \mathrm{SCH} 23390$ to $\mathrm{D}_{1}$ receptors in control animals was clearly heterogeneous with appreciable differences in the degree of binding among subregions of the striatum. Labeling was characterized by a distinct medial to lateral gradient with a higher density of $D_{1}$ receptors observed in more medial portions of the striatum (Figure 2, panel A). The highest concentration of receptors was evident in the olfactory tubercle. The distribution of the binding of $\left[{ }^{3} \mathrm{H}\right] \mathrm{SCH} 23390$, however, was similar at both rostral and caudal levels.

The overall pattern of $\left[{ }^{3} \mathrm{H}\right] \mathrm{SCH} 23390$ binding to $\mathrm{D}_{1}$ receptors in cocaine self-administering monkeys was generally similar to that observed in controls. Initial (5 sessions) exposure to the reinforcing effects of cocaine at either dose did not significantly alter the density of $\mathrm{D}_{1}$ receptor binding sites in the striatum, when compared with the density of receptors in the food-reinforced control monkeys (Table 2; Figure 2, panel B). The largest effects of initial cocaine exposure on $D_{1}$ receptor densities were in the rostral nucleus accumbens in which increases of $\sim+10$ and $+15 \%$ were observed following exposure of 4.5 and $45 \mathrm{mg} / \mathrm{kg}$ cocaine, respectively.

The effects of chronic ( $~ 100$ sessions) exposure to cocaine self-administration were characterized by increases in the density of $\left[{ }^{3} \mathrm{H}\right] \mathrm{SCH} 23390$ binding to $\mathrm{D}_{1}$ receptors throughout the striatum (Table 2; Figure 2, panel C). When compared with the densities of $\mathrm{D}_{1}$ receptors in the food-reinforced control monkeys, the chronic cocaine self-administration groups had significantly higher concentrations of $\mathrm{D}_{1}$ receptors in the dorsolateral and ventromedial caudate, dorsal and central putamen, the shell of the nucleus accumbens, and the olfactory tubercle (Figure 2, panels B and C). Although the increases seen in the putamen appeared to be dose-related, in that significant increases were only observed in the high-dose group ( $0.3 \mathrm{mg} / \mathrm{kg}$ per injection cocaine), the increased densities in other regions were of a similar magnitude regardless of the dose of cocaine self-administered.

\section{Effects of Cocaine Self-administration on $\mathrm{D}_{2}$ Receptor Binding in the Striatum}

Concentrations of $\left[{ }^{3} \mathrm{H}\right]$ raclopride binding to dopamine $\mathrm{D}_{2}$ receptors in the PCS, expressed in $\mathrm{fmol} / \mathrm{mg}$ wet- 


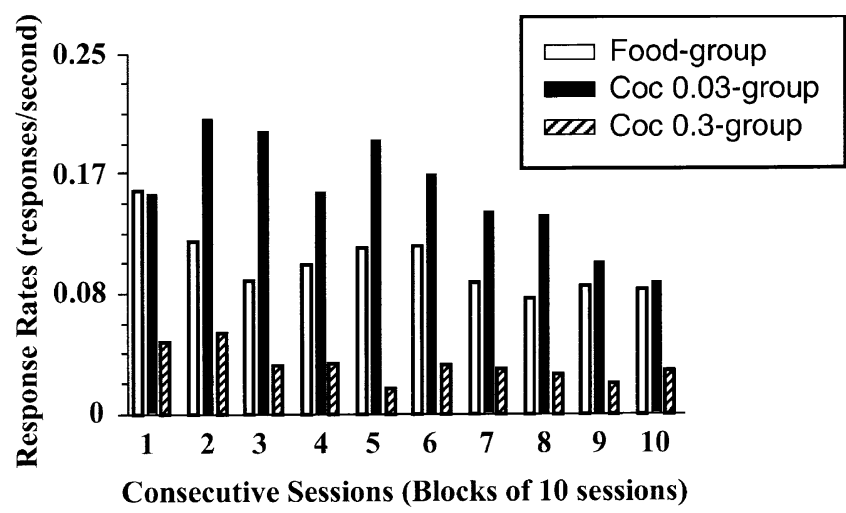

Figure 1. Rates of responding (responses per second) under a fixed-interval 3-min schedule of reinforcement for food-reinforced control monkeys ( $\mathrm{n}=2$; open bars), 0.03 $\mathrm{mg} / \mathrm{kg}$ cocaine per injection $(\mathrm{n}=4$; filled bars) and 0.3 $\mathrm{mg} / \mathrm{kg}$ cocaine per injection ( $\mathrm{n}=4$; hatched bars) monkeys, as a function of consecutive sessions (blocks of 10 sessions). Each bar represents group means ( \pm 1 S.E.M.) of 10 sessions.

weight tissue, are shown in Table 3. As described above, there were two separate control groups ( $n=3$ /group); there were no statistically significant differences in $\mathrm{D}_{2}$ receptor binding between control groups. Specific binding with $\left[{ }^{3} \mathrm{H}\right]$ raclopride accounted for greater than $90 \%$ of total binding. The distribution and density of binding to $D_{2}$ receptors was assessed in the same regions of the PCS as the $D_{1}$ receptors.

The distribution of $\left[{ }^{3} \mathrm{H}\right]$ raclopride binding to $\mathrm{D}_{2}$ receptors was distinctly heterogeneous across subregions of the dorsal and ventral striatum. In general, higher concentrations of $\mathrm{D}_{2}$ binding sites were present in more rostral portions of the PCS than at more caudal levels. Furthermore, a clear medial to lateral gradient was evident with a denser expression of $\mathrm{D}_{2}$ receptors apparent in the more lateral divisions of the striatum (Figure 3, panel A). Finally, binding was expressed more heavily in the dorsal striatum than in the ventral striatum. This overall pattern was present in tissue of animals in both food-reinforced control and cocaine self-administering groups.

Initial (5 sessions) exposure to the reinforcing effects of cocaine at either dose did not significantly alter the density of $\mathrm{D}_{2}$ receptor binding sites in the striatum, when compared with the density of receptors in the food-reinforced control monkeys (Table 3; Figure 3, panel B). Although the effects of cocaine were not significantly different from control values, there were consistent decreases of $\sim 10 \%$ in $\mathrm{D}_{2}$ receptor densities in the rostral PCS after five days of cocaine self-administration (see Table 3).

In contrast to $D_{1}$ receptors, chronic ( $\sim 100$ sessions) exposure to self-administered cocaine decreased the density of $\left[{ }^{3} \mathrm{H}\right]$ raclopride binding to $\mathrm{D}_{2}$ receptors throughout of the PCS (Table 3). Furthermore, the reductions in $\mathrm{D}_{2}$ binding densities were generally of a larger magnitude than the increases in $\mathrm{D}_{1}$ binding densities and were also more widespread, incorporating all striatal territories. At rostral levels of the PCS, significant reductions in the density of $\mathrm{D}_{2}$ receptors were evident in all portions of the caudate, as well as in the dorsal and central putamen. At caudal levels of the PCS, significant decreases in $\mathrm{D}_{2}$ receptor densities were seen in all portions of the caudate and putamen, as well as in the shell and core subdivisions of the nucleus accumbens (Figure 3, panel C). Changes at this level ranged from $-9 \%$ to $-28 \%$. In most cases, these effects were of similar degree following $0.03 \mathrm{mg} / \mathrm{kg}$ or $0.3 \mathrm{mg} / \mathrm{kg}$ per injection cocaine, although the decreases were larger in the shell and core of the nucleus accumbens and the ventromedial caudate following the $0.3 \mathrm{mg} / \mathrm{kg}$ cocaine dose.

\section{DISCUSSION}

The present findings suggest that the effects of cocaine on $D_{1}$ and $D_{2}$ receptor densities are both time- and dose-dependent. Brief exposure (5 sessions) to either a low or a high dose of cocaine did not significantly alter the density of either $D_{1}$ or $D_{2}$ receptors. However, more prolonged exposure ( $\sim 100$ sessions) resulted in robust and significant changes in $\mathrm{D}_{1}$ and $\mathrm{D}_{2}$ receptor densities throughout the precommissural striatum, particularly within the nucleus accumbens. In particular, chronic cocaine exposure decreased $D_{2}$ receptor densities, whereas it increased $D_{1}$ receptor densities.

The effect on $D_{2}$ receptors was widespread; receptor density was decreased in virtually every territory we examined. The effect on $D_{1}$ receptors was more variable, with some territories showing increases in receptor density, whereas other areas remained unchanged. There was also some evidence that these effects were dose related, in that larger effects were observed in monkeys self-administering the higher cocaine dose. These results, in a nonhuman primate model of cocaine self-administration, support the hypothesis that chronic cocaine alters the regulation of DA receptor density. Importantly, the present findings provide evidence that with chronic exposure to cocaine the changes in $\mathrm{D}_{1}$ and $\mathrm{D}_{2}$ receptors may not be in similar directions.

This study is the first to examine the effects of both initial and chronic exposure to cocaine self-administration on DA receptor numbers in nonhuman primates. In the present study, chronic exposure consisted of daily ( 7 days/week) cocaine self-administration, for approximately 100 sessions. The present findings, using reinforcing doses of cocaine and no withdrawal periods after the last self-administration session, suggest that initial (i.e., 5 days) exposure to cocaine reinforcement does not allow sufficient time for changes in DA $\mathrm{D}_{1}$ and $\mathrm{D}_{2}$ receptor densities to develop. Similarly, we recently 


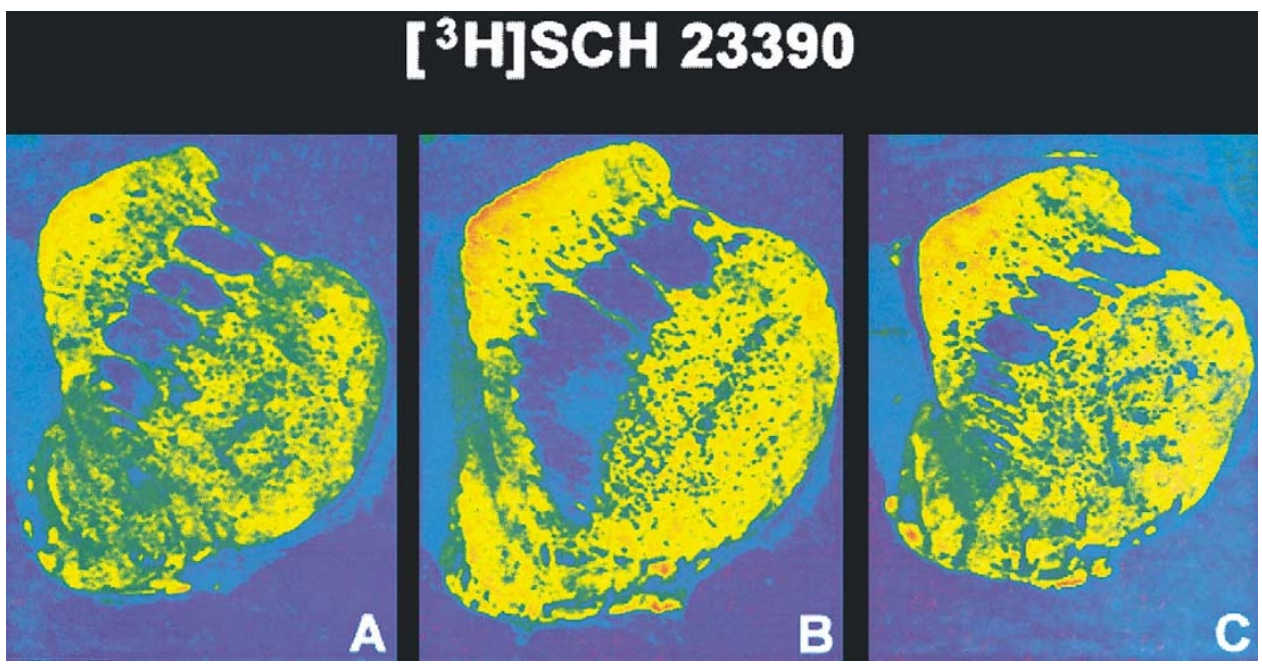

Figure 2. Representative color-coded autoradiograms depicting specific $\mathrm{D}_{1}$ binding using $\left[{ }^{3} \mathrm{H}\right] \mathrm{SCH} 23390$ at the level of the posterior ventral precommissural striatum of a control rhesus monkey (panel A) and from a representative monkey in the chronic $0.03 \mathrm{mg} / \mathrm{kg}$ cocaine per injection (panel B) and $0.3 \mathrm{mg} / \mathrm{kg}$ cocaine per injection (panel C) groups. The autoradiogram is scaled in $\mathrm{fmol} / \mathrm{mg}$ wet-weight tissue.

reported that in these same animals, five days of cocaine self-administration did not produce significant changes in DA transporter levels (Letchworth et al. 2001). Taken together, these findings suggest that daily cocaine exposure per se is not sufficient to produce neurobiological alterations. Rather, it appears that more prolonged exposure is necessary for neuropharmacological changes that may ultimately lead to addiction. We hypothesize that despite no significant effect of cocaine on receptor densities following five consecutive sessions of cocaine reinforcement, neuroadaptation to the effects of cocaine has begun and that receptor regu- lation is highly labile during that period. This may be one explanation for the variable results obtained from "chronic" cocaine studies, in which the cocaine exposure is relatively brief (see Introduction).

In the present study, chronic cocaine self-administration consisted of approximately 100 self-administration sessions and resulted in robust and significant changes in the expression of $D_{1}$ and $D_{2}$ receptors throughout the precommissural portions of the striatum. The decreases in $\mathrm{D}_{2}$ receptor density described in the present study are similar to the reductions we previously reported (Moore et al. 1998b; Nader et al. 2002) in monkeys that

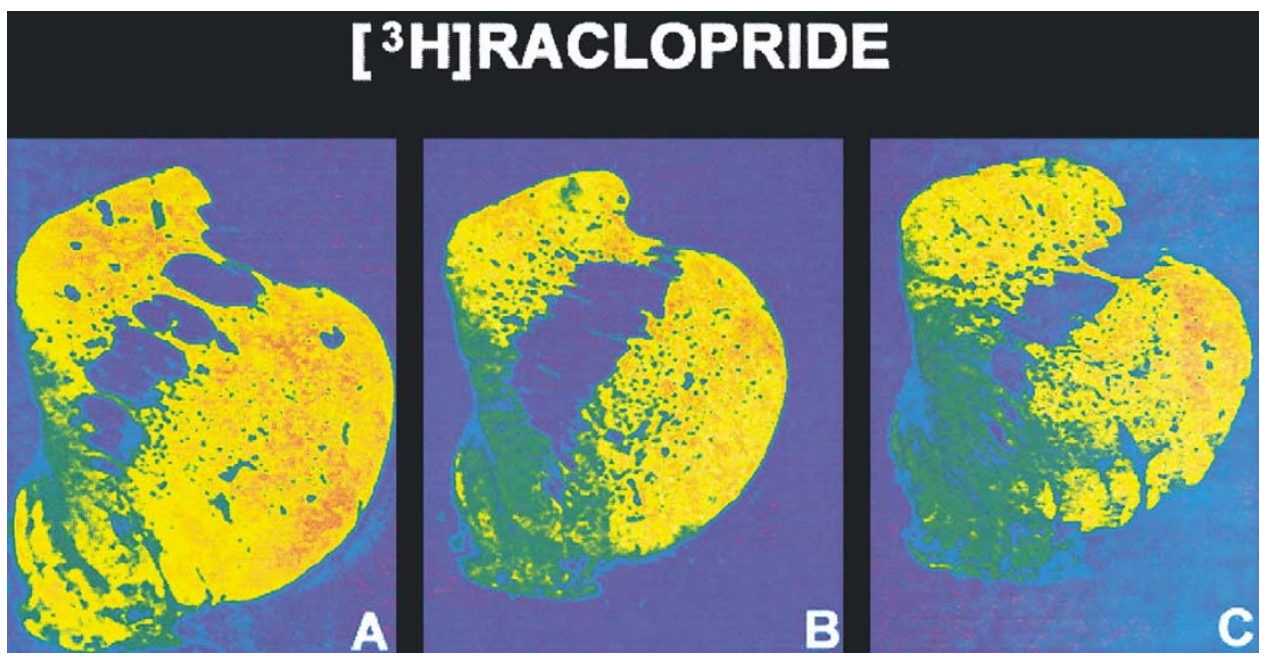

Figure 3. Representative color-coded autoradiograms depicting specific $\mathrm{D}_{2}$ binding using $\left[{ }^{3} \mathrm{H}\right]$ raclopride at the level of the posterior ventral precommissural striatum of a control rhesus monkey (panel A) and from a representative monkey in the chronic $0.03 \mathrm{mg} / \mathrm{kg}$ cocaine per injection (panel B) and $0.3 \mathrm{mg} / \mathrm{kg}$ cocaine per injection (panel C) groups. The autoradiogram is scaled in $\mathrm{fmol} / \mathrm{mg}$ wet-weight tissue. 
had self-administered cocaine for over 18 months. Both sets of findings are also consistent with data from PET imaging studies demonstrating that long-term cocaine exposure can produce decreases in $\mathrm{D}_{2}$ receptor binding potential in humans (Volkow et al. 1990, 1993). Importantly, levels of $\mathrm{D}_{2}$ receptors are closely related to the subjective effects of psychomotor stimulants, since subjects with lower levels of $D_{2}$ receptors reported positive subjective effects following methylphenidate, compared with subjects with higher levels of $\mathrm{D}_{2}$ receptors (Volkow et al. 1999). The present findings provide additional information about the timecourse and neuroanatomical location of the changes within the striatum of $\mathrm{D}_{2}$ receptor density, that may mediate cocaine's highly reinforcing effects.

Chronic cocaine self-administration also affected $\mathrm{D}_{1}$ receptor density in the striatum of monkeys. However, the significant increases in $\mathrm{D}_{1}$ receptor densities in some parts of the PCS following chronic cocaine exposure reported here are not consistent with our earlier report (Moore et al. 1998a), in which decreases in $D_{1}$ receptor density were observed. In our previous study, however, monkeys self-administered cocaine for 18 months, compared with 3.3 months in the present study. Considering the results of both sets of studies, one hypothesis generated from these data is that $D_{1}$ receptor density is differentially regulated over time with continued exposure to cocaine. That is, the initial increase in density that precedes a later decrease may represent two distinct mechanisms of $D_{1}$ receptor regulation. Support for this differential $D_{1}$ receptor regulation comes from the Farfel et al. (1992) study in which two weeks of cocaine administration followed by two weeks withdrawal resulted in a significant decrease in $D_{1}$ receptor density in the striatum.

The opposite regulation of $\mathrm{D}_{1}$ and $\mathrm{D}_{2}$ receptor densities by cocaine in the present study provides important information about the mechanisms of interaction between DA receptors and cocaine-induced elevations in extracellular DA. Within the striatum, $\mathrm{D}_{1}$ and $\mathrm{D}_{2}$ receptors are predominantly found on different populations of the medium spiny neurons that comprise the striatal output. $\mathrm{D}_{1}$ receptors, which facilitate neuronal firing, are found on neurons that express dynorphin, Substance P and GABA, and which project to the internal segment of the globus pallidus. $\mathrm{D}_{2}$ receptors, which inhibit neuronal firing, are found on neurons which express enkephalin and GABA and which project to the external segment of the globus pallidus.

These two populations of neurons modulate the output of the basal ganglia in opposite directions, but because the $D_{1}$ and $D_{2}$ receptors themselves have opposite effects on the neurons that express them, a global increase in DA levels, like the one caused by cocaine, would result in the two systems working additively to affect the final output of the basal ganglia. From this perspective, the upregulation of $D_{1}$ receptors may be seen as an attempted compensation for the downregulation of $\mathrm{D}_{2}$ receptors. However, it appears that continued exposure to cocaine (of up to 18 months) overcomes this compensatory mechanism, since both populations of receptors are eventually reduced (Moore et al. 1998a,b).

In the studies by Moore et al., monkeys had selfadministered 431-588 mg/ $\mathrm{kg}$ cocaine in their lifetime, compared with the $\sim 1000 \mathrm{mg} / \mathrm{kg}$ cocaine over a shorter period of time in the present study. Thus, it appears that the temporal course of neuroadaptation that accompanies cocaine self-administration may depend more on the duration of exposure than on the cumulative cocaine intake. Additionally, in some striatal regions, receptor density changes did not differ as a function of dose. This suggests that the changes were not due only to cumulative cocaine dose, but perhaps the entire process of "drug seeking", including the presentation of environmental cues such as discriminative stimuli and conditioned reinforcers. Observations made by Volkow et al. (1993) support this hypothesis. These investigators found that $\mathrm{D}_{2}$ receptor density was significantly correlated with years of cocaine use, but not with the cocaine doses used. These correlational data reported by Volkow et al. (1993), along with our findings in monkeys (Moore et al. 1998a,b; present study), suggest that it is not only the pharmacological effects of cocaine that alter DA receptor densities, but rather that the behavioral repertoire and environmental context have an important impact as well.

\section{ACKNOWLEDGMENTS}

This research was supported by National Institute on Drug Abuse research grants DA 09085, DA 00414 and P50 DA 06634. We thank David Lyons, Clifford Hubbard, Drake Morgan, Joshua Lile, Christopher Whitlow, Cory Freedland, Hannah Harris and Osric Prioleau for assistance in conducting these experiments.

\section{REFERENCES}

Bardo MT, Hammer RP Jr (1991): Autoradiographic localization of dopamine $D_{1}$ and $D_{2}$ receptors in rat nucleus accumbens: Resistance to differential rearing conditions. Neuroscience 45:281-290

Bergman J, Kamien JB, Spealman RD (1990): Antagonism of cocaine self-administration by selective dopamine $D_{1}$ and $\mathrm{D}_{2}$ antagonists. Behav Pharmacol 1:355-363

Bradberry CW (2000): Acute and chronic dopamine dynamics in a nonhuman primate model of recreational cocaine use. J Neurosci 20:7109-7115

Caine SB, Heinrichs SC, Coffin VL, Koob GF (1995): Effects of the dopamine D-1 antagonist SCH 23390 microinjected into the accumbens, amygdala or striatum on cocaine self-administration in the rat. Brain Res 692:47-56

Caine SB, Koob GF (1994): Effects of dopamine D-1 and D-2 antagonists on cocaine self-administration under differ- 
ent schedules of reinforcement in the rat. J Pharmacol Exp Ther 270:209-218

Caine SB, Negus SS, Mello NK (2000): Effects of dopamine $\mathrm{D}_{1^{-}}$ like and $\mathrm{D}_{2}$-like agonists on cocaine self-administration in rhesus monkeys: rapid assessment of cocaine doseeffect functions. Psychopharmacology (Berl) 148: 41-51

Caine SB, Negus SS, Mello NK, Bergman J (1999): Effects of dopamine $\mathrm{D}_{1 \text {-like }}$ and $\mathrm{D}_{2 \text {-like }}$ agonists in rats that selfadministered cocaine. J Pharmacol Exp Ther 291:353360

Catania AC, Reynolds GS (1968): A quantitative analysis of the responding maintained by interval schedules of reinforcement. J Exp Anal Behav 11:327-383

Corrigall WA, Coen KM (1991): Cocaine self-administration is increased by both D1 and D2 dopamine antagonists. Pharmacol Biochem Behav 39:799-802

Dworkin SI, Mirkis S, Smith JE (1995): Response-dependent versus response-independent presentation of cocaine: differences in the lethal effects of the drug. Psychopharmacology (Berl) 117:262-266

Dwoskin LP, Peris J, Yasuda RP, Philpott K, Zahniser NR (1988): Repeated cocaine administration results in supersensitivity of striatal D-2 dopamine autoreceptors to pergolide. Life Sci 42:255-262

Farfel GM, Kleven MS, Woolverton WL, Seiden LS, Perry BD (1992): Effects of repeated injections of cocaine on catecholamine receptor binding sites, dopamine transporter binding sites and behavior in rhesus monkeys. Brain Res 578:235-243

Goeders NE, Kuhar MJ (1987): Chronic cocaine administration induces opposite changes in dopamine receptors in the striatum and nucleus accumbens. Alcohol Drug Res 7:207-216

Katz JL, Witkin JM (1992): Selective effects of the D1 dopamine receptor agonist SKF 38393, on behavior maintained by cocaine injection in squirrel monkeys. Psychopharmacology (Berl) 109:241-244

Kleven MS, Perry BD, Woolverton WL, Seiden LS (1990): Effects of repeated injections of cocaine on D1 and D2 dopamine receptors in rat brain. Brain Res 532:265-270

Lamas X, Negus SS, Nader MA, Mello NK (1996): Effects of the putative dopamine $\mathrm{D}_{3}$ receptor agonist 7-OH-DPAT in rhesus monkeys trained to discriminate cocaine from saline. Psychopharmacology (Berl) 124:306-314

Letchworth SR, Nader MA, Smith HR, Vinsant SL, Moore RJ, Friedman DP, Porrino LJ (2001): Cocaine self-administration in rhesus monkeys: progression of changes in dopamine transporter binding site density. J Neurosci 21: $2799-2807$

Lidow MS, Goldman-Rakic PS, Gallager DW, Rakic P (1991): Distribution of dopaminergic receptors in the primate cerebral cortex: Quantitative autoradiographic analysis using $\left[{ }^{3} \mathrm{H}\right]$ raclopride, $\left[{ }^{3} \mathrm{H}\right]$ spiperone and $\left[{ }^{3} \mathrm{H}\right] \mathrm{SCH} 23390$. Neuroscience 40:657-671

Lim DK, Yu ZJ, Hoskins B, Rockhold RW, Ho IK (1990): Effects of acute and subacute cocaine administration on the CNS dopaminergic system in Wistar-Kyoto and spontaneously hypertensive rats: II. Dopamine receptors. Neurochem Res 15:621-627

Lyons D, Friedman DP, Nader MA, Porrino LJ (1996): Acute cocaine administration alters cerebral metabolism within interconnected regions of the ventral striatum and limbic cortex of cynomolgus monkeys. J Neurosci $16: 1230-1238$

Maggos CE, Tsukada H, Kakiuchi T, Nishiyama S, Myers JE, Kreuter J, Schlussman SD, Unterwald EM, Ho A, Kreek MJ (1998): Sustained withdrawal allows normalization of in vivo $\left[{ }^{11} \mathrm{C}\right] \mathrm{N}$-methylspiperone dopamine $\mathrm{D}_{2}$ receptor binding after chronic binge cocaine: a positron emission tomography study in rats. Neuropsychopharmacology 19:146-153

Meador-Woodruff JH, Little KY, Damask SP, Mansour A, Watson SJ (1993): Effects of cocaine on dopamine receptor gene express: a study in the postmortem human brain. Biol Psychiatry 34:348-355

Memo M, Pradhan S, Hanbauer I (1981): Cocaine-induced supersensitivity of striatal dopamine receptors: Role of endogenous calmodulin. Neuropharmacology 20:1145-1150

Moore RJ, Vinsant SL, Nader MA, Porrino LJ, Friedman DP (1998a): The effect of cocaine self-administration on striatal dopamine $D_{1}$ receptors in rhesus monkeys. Synapse 28:1-9

Moore RJ, Vinsant SL, Nader MA, Porrino LJ, Friedman DP (1998b): Effect of cocaine self-administration on dopamine $\mathrm{D}_{2}$ receptors in rhesus monkeys. Synapse 30:88-96

Nader MA, Gage HD, Mach RH, Morgan D (2002): The use of PET imaging to examine the effects of cocaine and socially derived stress on dopamine $D_{2}$ receptors in nonhuman primates. In Harris LS (ed), "Problems of Drug Dependence 2001, Proceedings of the $63^{\text {rd }}$ Annual Meeting". NIDA Research Monograph, U.S. Government Printing Office, Washington, D.C., in press.

Nader MA, Green KL, Luedtke RR, Mach RH (1999): The effects of benzamide analogues on cocaine self-administration in rhesus monkeys. Psychopharmacology (Berl) 147:143-152

Nader MA, Mach RH (1996): The reinforcing effects of the putative dopamine $\mathrm{D}_{3}$ agonist 7-OH-DPAT in rhesus monkeys: Effects of cocaine self-administration history. Psychopharmacology (Berl) 125:13-22

Nader MA, Reboussin DM (1994): The effects of behavioral history on cocaine self-administration in rhesus monkeys. Psychopharmacology (Berl) 115:53-58

Peris J, Boyson SJ, Cass WA, Curella P, Dwoskin LP, Larson G, Lin L-H, Yasuda RP, Zahniser NR (1990): Persistence of neurochemical changes in dopamine systems after repeated cocaine administration. J Pharmacol Exp Ther 253:38-44

Ritz MC, Lamb RJ, Goldberg SR, Kuhar MJ (1987): Cocaine receptors on dopamine transporters are related to selfadministration of cocaine. Science 237:1219-1223

Roberts DCS, Phelan R, Hodges LM, Hodges MM, Bennett BA, Childers SR, Davies H (1999): Self-administration of cocaine analogs by rats. Psychopharmacology (Berl) 144: 389-397

Self DW, Barnhart WJ, Lehman DA, Nestler EJ (1996): Opposite modulation of cocaine-seeking behavior by D1- and D2like dopamine receptor agonists. Science 271:1586-1589

Self DW, Stein L (1992): The $D_{1}$ agonists SKF 82958 and SKF 77434 are self-administered by rats. Brain Res 582: 349-352

Sinnott RS, Mach RH, Nader MA (1999): The role of dopamine $\mathrm{D}_{3}$ receptors in the reinforcing and discriminative 
stimulus effects of cocaine in rhesus monkeys. Drug Alcohol Dep 54:97-110

Sinnott RS, Nader MA (2001): Modulation of cocaine's discriminative stimulus effects by dopamine $\mathrm{D}_{1}$ agonists in rhesus monkeys. Pharmacol Biochem Behav (in press)

Spealman RD, Bergman J, Madras BK, Melia KF (1991): Discriminative stimulus effects of cocaine in squirrel monkeys: Involvement of dopamine receptor subtypes. J Pharmacol Exp Ther 258:945-953

Spealman RD, Bergman J, Rosenzweig-Lipson S (1997): Differential modulation of behavioral effects of cocaine by low- and high-efficacy D1 agonists. Psychopharmacology (Berl) 133:283-292

Staley JK, Mash DC (1996): Adaptive increase in D3 dopamine receptors in the brain reward circuits of human cocaine fatalities. J Neurosci 16:6100-6106

Stefanski R, Ladenheim B, Lee SH, Cadet JL, Goldberg SR (1999): Neuroadaptations in the dopaminergic system after active self-administration but not after passive administration of methamphetamine. Eur J Pharmacol 371:123-135

Taylor DL, Ho BT, Fagan JD (1979): Increased dopamine receptor binding in rat brain by repeated cocaine injections. Comm. Psychopharmacology 3:137-142

Trulson ME, Ulissey MJ (1987): Chronic cocaine administration decreases dopamine synthesis rate and increases $\left[{ }^{3} \mathrm{H}\right]$ spiroperidol binding in rat brain. Brain Res Bull 19:35-38

Volkow ND, Fowler JS, Wolf AP, Schlyer D, Shiue C-Y,
Alpert R, Dewey SL, Logan J, Bendriem B, Christman D, Hitzemann R, Henn F (1990): Effects of chronic cocaine abuse on postsynaptic dopamine receptors. Am J Psychiatry 147:719-724

Volkow ND, Fowler JS, Wang G-J, Hitzemann R, Logan J, Schyler DJ, Dewey SL, Wolf AP (1993): Decreased dopamine $D_{2}$ receptor availability is associated with reduced frontal metabolism in cocaine abusers. Synapse 14:169177

Volkow ND, Wang G-J, Fowler JS, Logan J, Gatley SJ, Wong C, Hitzemann R, Pappas NR (1999): Reinforcing effects of psychostimulants in humans are associated with increases in brain dopamine and occupancy of $\mathrm{D}_{2}$ receptors. J Pharmacol Exp Ther 291:409-416

Weed MR, Vanover KE, Woolverton WL (1993): Reinforcing effect of the dopamine D1 agonist SKF 81297 in rhesus monkeys. Psychopharmacology (Berl) 113:51-52

Weed MR, Paul IA, Dwoskin LP, Moore SE, Woolverton WL (1997): The relationship between reinforcing effects and in vitro effects of D1 agonists in monkeys. J Pharmacol Exp Ther 283:29-38

Weed MR, Woolverton WL (1995): The reinforcing effects of dopamine D1 receptor agonists in rhesus monkeys. J Pharmacol Exp Ther 275:1367-1374

Woolverton WL, Johnson KM (1992): Neurobiology of cocaine abuse. Trends Pharmacol Sci 13:193-200

Woolverton WL, Virus RM (1989): The effects of a D1 and a D2 dopamine antagonist on behavior maintained by cocaine or food. Pharmacol Biochem Behav 32:691-697 